\title{
Penggunaan Sistem Klasifikasi Di Perpustakaan Daerah Provinsi Lampung Sebagai Bentuk Peningkatan Pengelolaan Perpustakaan
}

\author{
Mezan el-Khaeri Kesuma ${ }^{1}$, Irva Yunita ${ }^{2 *}$, Mutiara Cahyani Putri ${ }^{3}$ \\ ${ }^{123}$ Fakultas Ada, Universitas Islam Negeri Raden Intan Lampung \\ ${ }^{123} \mathrm{Jl}$ Endo Suratmin Sukarame 1 Bandar Lampung, 35131 \\ Correspondence e-mail: irva@ radenintan.ac.id
}

\begin{abstract}
Introduction. The material discussed in this journal is to explain and describe in detail the use of the classification system at the Regional Library of Lampung Province, what system is used, how it is used.

Data Collection Methods. The method used in this journal research is interview research and documentation study. The author also uses qualitative methods and literature studies.

Data Analysis. Analysis of the data using data reduction, data presentation, and make conclusions about the Regional Library of Lampung Province.

Results and Discussion. The results of this study are that the Lampung Provincial Library Service uses 2 classification systems, namely a manual system and also a digital system with the E-DDC application. The librarian at the Lampung Provincial Library Service uses E-DDC edition 23, although using two classification systems, the librarian at the Lampung Provincial Library Service still uses a manual system more often because if you use a digital system with the E-DDC application the librarian sometimes has problems when using it, however, the use of the E-DDC application is still being used today.

Conclusion. The use of the classification system in the Regional Library of Lampung Province uses two classification systems, namely the manual system and the E-DDC (Electronic-Dewey Decimal Classification) application. The manual system is still often used by librarians of the Lampung Province Regional Library, even so, the E-DDC application is still used but rarely because sometimes it gets obstacles when you want to use it.
\end{abstract}

Keyword: Classification, Library Management, Regional Library of Lampung Province

\begin{abstract}
ABSTRAK
Pendahuluan. Materi yang dibahas dalam jurnal ini adalah menjelaskan dan mendeskripsikan secara detail penggunaan sistem klasifikasi pada Perpustakaan Daerah Provinsi Lampung, sistem apa yang digunakan, bagaimana penggunaannya.

Metode penelitian. Metode yang digunakan dalam penelitian jurnal ini adalah penelitian wawancarai dan studi dokumentasi. Penulis juga menggunakan metode kualitatif dan studi pustaka..

Data analisis. Analisis Data yang digunakan adalah reduksi data, penyajian data, dan menarik kesimpulan mengenai Perpustakaan Daerah Provinsi Lampung.

Hasil dan Pembahasan. Hasil dari penelitian ini adalah Perpustakaan Daerah Provinsi Lampung menggunakan 2 sistem klasifikasi yaitu sistem manual dan juga sistem digital dengan aplikasi E-DDC. Pustakawan di Perpustakaan Daerah Provinsi Lampung
\end{abstract}


menggunakan E-DDC edisi 23, meskipun menggunakan dua sistem klasifikasi, pustakawan di Perpustakaan Daerah Provinsi Lampung masih lebih sering menggunakan sistem manual karena jika menggunakan sistem digital dengan aplikasi E$D D C$, pustakawan terkadang mengalami kendala saat menggunakannya, namun penggunaan aplikasi E-DDC masih tetap digunakan hingga saat ini.

Kesimpulan. Penggunaan sistem klasifikasi di Perpustakaan Daerah Provinsi Lampung menggunakan dua sistem klasifikasi yaitu dengan sistem manual dan aplikasi E-DDC (Electronic-Dewey Decimal Classification). Sistem manual masih sering digunakan pustakawan Perpustakaan Daerah Provinsi Lampung, meskipun begitu aplikasi E-DDC masih tetap digunakan tetapi jarang, karena terkadang mendapatkan kendala saat ingin menggunakannya.

Kata Kunci: Klasifikasi, Pengelolaan Perpustakaan, Perpustakaan Daerah Provinsi Lampung

\section{A. PENDAhuluan}

Perpustakaan Daerah Provinsi Lampung yang terletak di Jl. Wolter Monginsidi, Pengajaran, Kec. Teluk Betung Utara, Kota Bandar Lampung. Sebelum menjadi nama seperti sekarang erpustakaan Daerah Provinsi Lampung memiliki profil/sejarah yang cukup Panjang yang dimulai dari awal dari nama perpustakaan ini yaitu Perpustakaan Wilayah Departemen Pendidikan dan Kebudayaan Provinsi Lampung. Setelah itu nama Perpustakaan Wilayah tersebut berubah lagi menjadi menjadi Perpustakaan Daerah Lampung sesuai dengan terbitnya Keppres RI No. 11 tahun 1989, selanjutnya dalam meningkatkan status perpustakaan terbitlah Keppres RI No. 50 tahun 1997 yang menjadikan status Perpustakaan Daerah Provinsi Lampung menjadi Perpustakaan Nasional Provinsi Lampung. Singkatnya pada tanggal 12 Desember 2007 ditetapkanlah Perpustakaan Daerah dan Kantor Arsip Daerah digabung dan menjadi nama Badan Perpustakaan, Arsip, dan Dokumentasi Daerah Provinsi Lampung, kemudian pada Peraturan Daerah Provinsi Lampung No. 8 tahun 2016 Badan Perpustakaan, Arsip, dan Dokumentasi berubah nama lagi menjadi Dinas Perpustakaan dan Kearsipan Provinsi Lampung (Perpusda Provinsi Lampung, 2021).

Perpustakaan adalah sebuah lembaga informasi untuk dapat menunjang sebuahpendidikan baik formal atau pun non formal. Perpustakaan merupakan sebuah ajang perubahan bagi sebuah komunitas untuk dapat menunjang pendidikan yang lebih tinggi (Kesuma, Yunita \& Meilani: 2021). Dalam mempersipakan layanan terbaiknya, perpustakaan harus mempertimbangkan 
segala sesuatunya agar dapat memberikan layanan prima kepada pemustaka. Salah satunya dalam dalam pelayanan klasifikasi koleksi buku perpustakaan (Indah, 2020). Koleksi perpustakaan adalah semua bahan pustaka yang dikumpulkan, diolah dan disimpan untuk disebarluaskan kepada masyarakat guna memenuhi kebutuhan informasi mereka (Fijas, Marlini: 2021).

Perpustakaan sendiri difungsikan untuk dapat menyediakan koleksi, memberikan informasi, bahkan melestarikan dan menyimpan berbagai karya sebagai acuan atau keperluan dalam penelitian \& pendidikan (Sipil, 2017). Di suatu perpustakaan itu sendiri pasti terdapat sebuah pengklasifikasian atau sistem klasifikasi yang digunakan baik itu secara manual maupun yang sudah berbasis digital. Klasifikasi merupakan kegiatanmengelompokkan dan menggolongkan bahan pustaka. Klasifikasi yang sering digunakan oleh pustakawan di suatu perpustakaan yaitu klasifikasi DDC (Dewey Decimal Classification), klasifikasi DDC tersebut diterbitkan oleh sebuah OCLC yang merupakan suatu perpustakaan pusat komputer online dimana memiliki seluruh hak cipta dari klasifikasi tersebut yang dapat digunakan oleh semua pengguna (Dedy \& Saputra, 2018). Suatu perpustakaan membutuhkan proses pengklasifikasian terhadap dokumen dan bahan pustakan nya secara akurat(Fadilla, 2021), di era digital saat ini perpustakaan-perpustakaan juga sudah banyak yang menggunakan sistem klasifikasi digital atau dengan menggunakan aplikasi E-DDC (Electronic-Dewey Decimal Classification) sebagai bentuk dari efisiensi waktu dalam menentukan nomor klasifikasi bahan pustaka nya. Seperti hal nya di Perpustakaan Daerah Provinsi Lampung yang menggunakan dua sistem klasifikasi dalam menentukan nomor klasifikasi nya (Hutasoit, 2014).

\section{B. TINJAUAN PUSTAKA}

Klasifikasi diartikan sebagai suatu susunan yang bersistem kemudian digolongkan dan dikelompokkan sesuai dengan aturan dan standar yang sudah ditetapkan (Sugono, 2008:706). Bagan klasifikasi adalah skema dari suatu klasifikasi yang menjelaskan kelas yang terdapat di dalam klasifikasi untuk menunjukkan hubungan yang hierarkhi, sedangkan untuk indeks 
subyek merupakan rincian istilah yang tersusun secara alfabetis untuk menjelaskan dan menguraikan berbagai pengertian (Lasa, 2009: 34).

Sistem klasifikasi DDC merupakan proses mengklasifikasi dan juga mengelompokkan bahan pustaka nya yang disesuaikan dengan subyek kemudian tersusun secara sistematis sehingga pemustaka dapat dengan mudah menemukan bahan pustaka. (Hastari, 2015). Klasifikasi yaitu kegiatan mengelompokkan bahan Pustaka yang disesuaikan dengan kumpulan subyek, bentuk, objek, dan lain-lain yang ditentukan dengan sistem bertujuan untuk mempermudah penelusuran, penemuan bahkan letak bahan pustaka di rak (Darwis: 2014, 3). Sistem klasifikasi yang baik yaitu adanya suatu badan yang dapat mengawasi pada perkembangan klasifikasi terutama pada bagan klasifikasi nya sehingga selalu terbaru dan tidak tertinggal dengan perkembangan zaman (WorldCat, 2019).

Ketiadaan sistem klasifikasi dan pencarian buku mengharuskan para mahasiswa pengunjung perpustakaan untuk melakukan pencarian buku secara manual. Pengelola perpustakaan juga belum dapat menata buku berdasarkan kategori buku yang sesuai karena ketidaktahuan kategori yang dimiliki pada tiap buku yang tersedia (Risqiani, Mulwinda, Mahadji, 2017).

Sistem klasifikasi di perpustakaan bisa berdasarkan ciri-ciri buku, sehingga buku yang dicirikan sama, bisa dikelompokkan jadi satu. Adapun beberapa sistem klasifikasi buku di perpustakaan menurut Bafadal antara lain sebagai berikut:

1. Sistem abjad nama pengarang : Pada sistem ini, buku-buku perpustakaan dikelompokkan berdasarkan abjad nama pengarangnya. Buku-buku yang huruf pertama dari pengarangnya sama dikelompokkan menjadi satu.

2. Sistem abjad judul buku: Pada sistem ini, buku-buku perpustakaan dikelompokkan berdasarkan abjad judul buku. Buku-buku yang huruf pertama dari judul sama dikelompokkan jadi satu.

3. Sistem kegunaan buku: Pada sistem ini, buku-buku di perpustakaan dikelompokkan berdasarkan kegunaan. Buku-buku referensi dikelompokkan menjadi satu, buku-buku cerita dikelompokkan jadi satu, buku-buku ilmu pengetahuan dikelompokkan menjadi satu, dan sebagainya. 
4. Sistem penerbit: Pada sistem ini, buku perpustakaan dikelompokkan berdasarkan penerbit buku. Di Indonesia terdapat banyak penerbit, seperti Usaha Nasional, Balai Pustaka, Balai Aksara, Gramedia, dan sebagainya. Buku-buku yang penerbitnya sama dikelompokkan menjadi satu dan ditempatkan pada satu tempat tertentu.

5. Sistem bentuk fisik: Pada sistem ini, buku-buku diperpustakaan dikelompokan berdasarkan bentuk fisiknya. Ditinjau dari bentuk fisiknya, bahan pustaka ada yang berupa buku dan adapula yang berupa bukan buku seperti majalah, surat kabar, brosur dan sebagainya. Maka bahan pustaka yang berbentuk buku dikelompokkan menjadi satu, begitupun dengan yang lainnya. Buku-buku di perpustakaan bias juga dikelompokkan lebih spesifik lagi berdasarkan ukurannya, misalnya luasnya, ketebalanya, tipisnya, ringan beratnya.

6. Sistem bahasa: Pada sistem ini, buku diperpustakaan dikelompokkan berdasarkan Bahasa yang digunakan. Buku perpustakaan yang berbahasa Indonesia dikelompokkan menjadi satu, buku perpustakaan yang berbahasa asing seperti Bahasa Inggris dikelompokkan menjadi satu, begitu pula dengan buku yang berbahasa daerah seperti Jawa dikelompokkan menjadi satu.

7. Sistem subjek: Pada sistem ini, buku perpustakaan dikelompokkan berdasarkan subjek atau isi yang terkandung di dalam buku yang bersangkutan. Misalnya buku yang membahas tentang Pendidikan dikelompokkan menjadi satu, buku yang membahas tentang kesehatan dikelompokkan menjadi satu, dan sebagainya (Bafadhal, 2016: 55)

Unsur-unsur pokok DDC (Dewey Decimal Clasification) sistem ini memiliki unsur-unsur pokok sebagai berikut:

1. Sistematika pembagian ilmu pengetahuan yang dituangkan kedalam satu bagan yang lengkap dan dilandaskan pada beberapa prinsip dasar tertentu.

2. Notasi, yang terdiri dari serangkaian simbol berupa angka, yang mewakili serangkaian istilah, (yang mencerminkan subjek tertentu) yang terdapat pada bagan

3. Indeks relative, yang terdiri dari sejumlah tajuk dengan perincian aspekaspeknya yang disusun secara alfabetis, dan memberikan petunjuk berupa 
nomor kelas, yang memungkinkan orang mencari tajuk yang tercantum dalam indeks bagan.

4. Tabel pembantu, yang membentuk serangkaian notasi khusus, yang dipakai untuk menyatakan aspek-aspek tertentu yang selalu terdapat dalam beberapa subjek yang berbeda, terdapat enam tabel pembantu yaitu:

a) Tabel-1: Subdivisi Standar.

b) Tabel-2: Wilayah.

c) Tabel-3: Subdivisi Kesusastraan.

d) Tabel-4: Subdivisi Bahasa.

e) Tabel-5: Ras, Bahasa, Kelompok Etnis.

f) Tabel-6: Bahas-Bahasa (Mutia \& Suherman, 218).

\section{METODE PENELITIAN}

Dalam penelitian ini penulis menggunakan metode penelitian secara langsung dengan berkunjung, mewawancarai salah satu pustakawan bagian sub bidang akuisisi yang ada di Perpustakaan Daerah Provinsi Lampung tersebut, dan melakukan studi dokumentasi. Selain itu penulis juga menggunakan metode kualitaif untuk dapat mengungkapkan, menjelaskan, dan memfokuskan pembahasan sesuai dengan fakta yang ada sesuai dengan data yang diperoleh dari hasil penelitian (Lisda, Harahap, Husna: nd). Metode selanjutnya yaitu penelitian kepustakaan yang memperoleh data melalui buku bacaan, karya tulis ilmiah dan sumber bahan bacaan lainnya yang disesuaikan dengan judul penelitian ini.

\section{HASIL DAN PEMBAHASAN}

Sistem klasifikasi di perpustakaan yang difungsikan untuk menyusun bahan pustaka secara sistematis berdasarkan subyek dan cakupan ilmu pengetahuan nya agar dapat mempermudah pemustaka dalam menemukan bahan pustaka yang dibutuhkan karena sudah diletakkan dan tersusun dengan rapi di dalam rak. Tujuan dari klasifikasi DDC itu sendiri yaitu untuk pemahaman dan masukan kepada pustakawan dalam manajemen pengelolaan bahan pustaka secara menyeluruh. Karena klasifikasi DDC lebih sering digunakan oleh perpustakaan, maka dari itu DDC memiliki beberapa unsur yang perlu diterapkan meliputi : 
1. Memiliki unsur yang sistematika, maksudnya yaitu di dalam bagan DDC tercantum dengan lengkap pembagian dari ilmu pengetahuan nya.

2. Memiliki unsur notasi, maksudnya yaitu memiliki simbol-simbol angka berupa angka arab dalam mewakili suatu subyek.

3. Memiliki unsur indeks relatif, maksudnya yaitu perincian aspek dari beberapa tajuk yang tersedia tersusun secara alfabetis serta tersedia juga petunjuk berupa nomor klasifikasi atau nomor kelas. Jika subyek sudah ditemukan notasinya melalui indeks relarif maka harus ada pengecekkan terhadap notasi yang terdapat pada bagan tersebut, sehingga nanti akan diketahui notasi yang sesuai dengan bahan pustaka yang di klasifikasi.

4. Memiliki unsur berupa tabel pembantu, maksudnya yaitu terdapat notasinotasi khusus untuk menyatakan suatu aspek, terdapat pada beberapa subyek yang berbeda.

5. Memiliki unsur berupa pembagian subyek, maksudnya yaitu di dalam DDC terdiri dari subyek besar atau kelas utama, kemudian menjadi sub yang kecil atau disebut devisi, kemudian menjadi sub yang lebih kecil lagi disebut subdivisi, dan yang terakhir menjadi lebih rinci berupa tabel lengkap (Nugroho, 2015).

Untuk sistem klasifikasi yang digunakan di Perpustakaan Daerah Provinsi Lampung menggunakan 2 sistem klasifikasi yaitu sistem klasifikasi manual dan klasifikasi digital dengan aplikasi E-DDC (Electronic-Dewey Decimal Classification). Penerapan dan penentuan nomor klasifikasi dengan cara manual yang dilakukan oleh pustakawan di Perpustakaan Daerah Provinsi Lampung menggunakan 7 buku pedoman klasifikasi DDC yang terbitkan oleh Perpustakaan Nasional RI, tidak hanya menggunakan buku pedoman klasifikasi umum tetapi juga menggunakan buku pedoman subyek Islam dan klasifikasi Islam. 


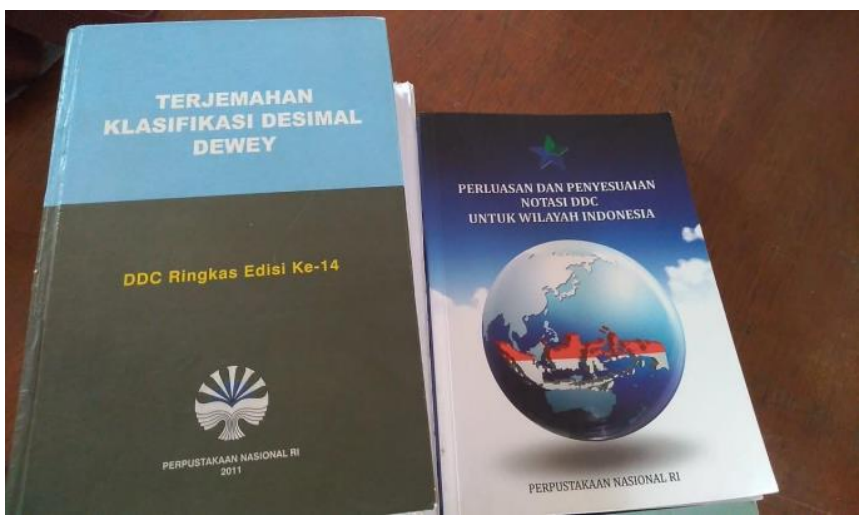

Gambar 1. Buku Pedoman Klasifikasi DDC

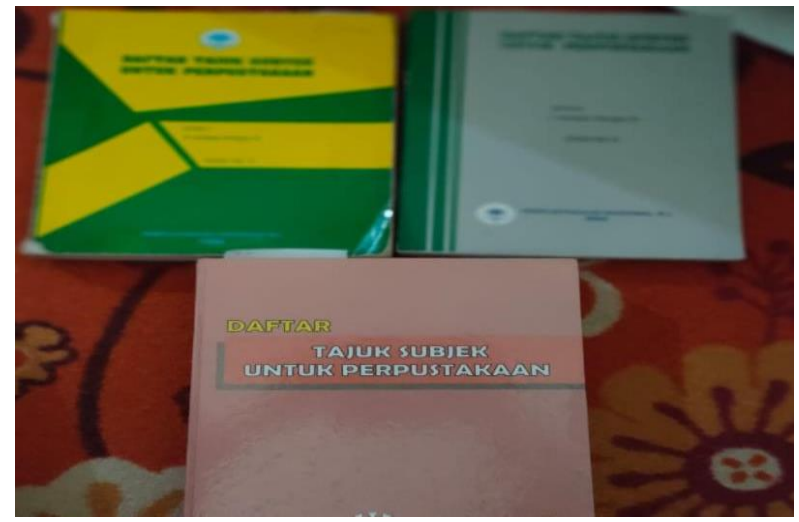

Gambar 1.2. Buku Pedoman Tajuk Subyek

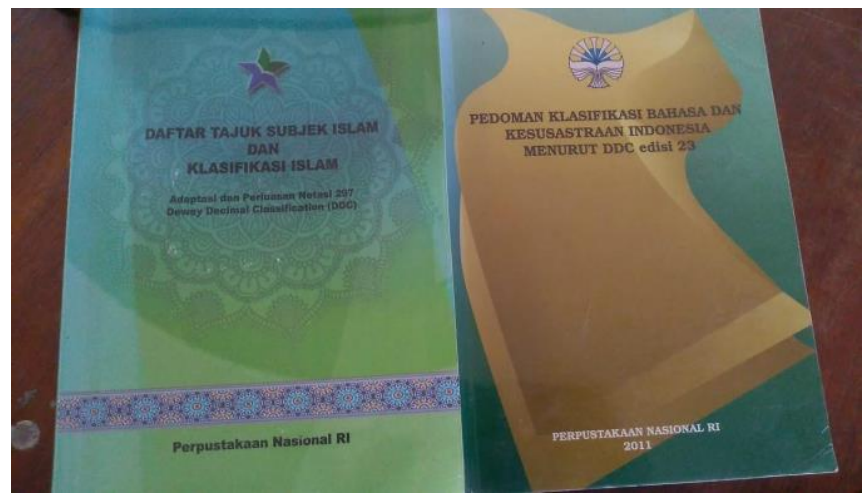

Gambar 1.3. Buku Pedoman Klasifikasi

Seperti yang dapat dilihat pada gambar diatas bahwa penggunaan buku pedoman klasifikasi yang digunakan oleh pustakawan tersebut memiliki edisi yang berbeda, seperti pada buku pedoman klasifikasi terjemahan klasifikasi desimal dewey yang merupakan 
edisi ke-14 untuk versi ringkas nya sedangkan untuk versi lengkap nya menggunakan edisi ke-22. Pada buku pedoman tajuk subyek untuk yang diluar subyek Islam memiliki 3 edisi yang dapat dibedakan juga warna pada sampul buku tersebut. Penggunaan 7 buku pedoman tersebut difungsikan untuk keseragaman seluruh perpustakaan yang menggunakannya, dan juga untuk memberikan nomor klasifikasi serta subyek dari bahan pustaka nya secara pasti.

Seperti yang diketahui bahwa penentuan nomor klasifikasi dapat dilakukan dengan menggunakan aplikasi E-DDC (Electronic-Dewey Decimal Classification) yang penggunaan dimulai dari menggunakan versi pertama yaitu pada tahun 2010 sampai dengan edisi yang digunakan sekarang yaitu edisi 23. Sedangkan untuk penggunaan sistem klasifikasi digital dengan menggunakan aplikasi E-DDC (Electronic-Dewey Decimal Classification) Perpustakaan Daerah Provinsi Lampung menggunakan E-DDC edisi ke-23.

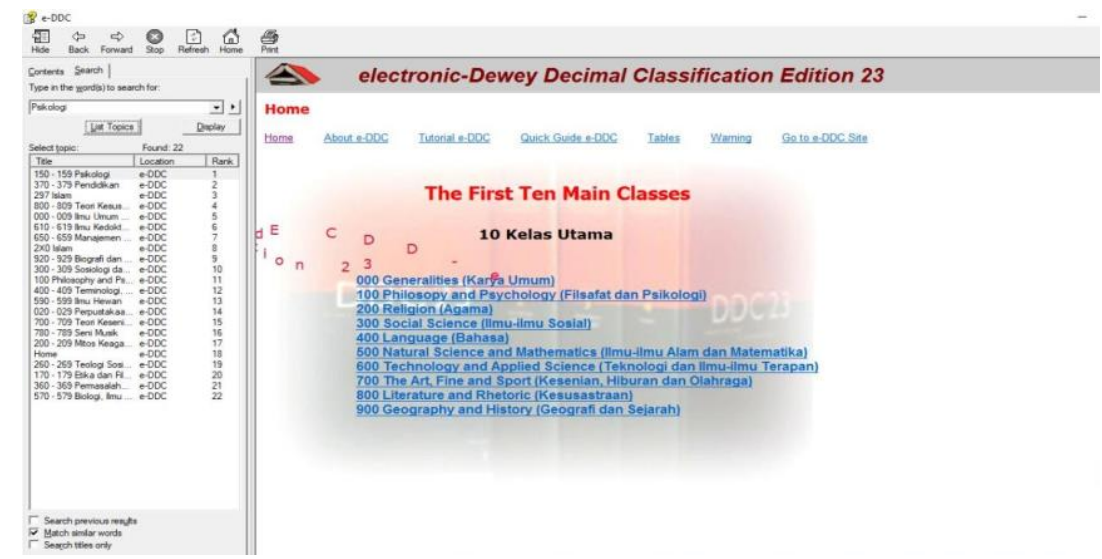

Gambar 1.4. Pencarian Pada E-DDC edisi 23

Untuk mencari nomor klasifikasi yang dicari dengan cepat, pengguna cukup memilih/mengklik pada search dan memasukkan kata kunci yang ingin dicari, seperti pada contoh diatas kata kunci yang ingin dicari yaitu Psikologi, setelah itu klik list topics dan akan muncul beberapa title yang berkaitan dengan subyek yang dicari tadi, selain akan muncul beberapa title tersebut akan muncul juga rank atau peringkat pencarian dan pilihlah rank 1 yang memang sangat berkaitan dengan subyek yang dicari yaitu psikologi. 


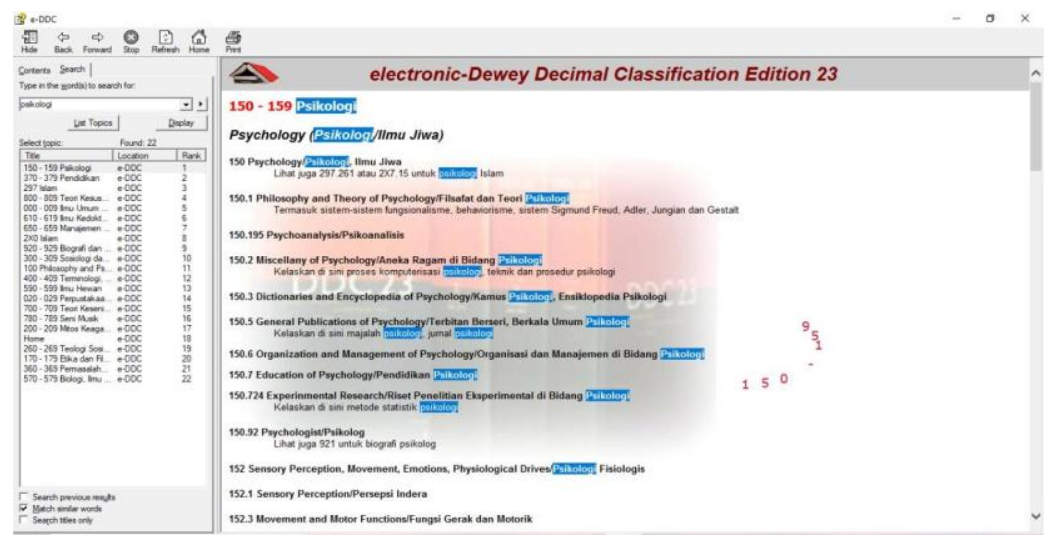

Gambar 1.5. Tampilan Nomor Klasifikasi E-DDC

Lalu setelah klik rank 1 untuk subyek psikologi dengan nomor klasifikasi 159-159, maka akan muncul tampilan seperti pada gambar diatas dengan subyek beserta nomor klasifikasi sesuai dengan dengan kata kunci psikologi yang sudah dicari tadi. Seperti misalnya subyek yang dicari berhubungan dengan pendidikan psikologi berarti nomor klasifikasi nya yaitu 150.7 untuk education of psychology/ pendidikan psikologi. Setelah menemukan subyek beserta nomor klasifikasi nya, lalu pustakawan hanya tinggal mencantumkan nomor klasifikasi tersebut pada bahan pustaka nya saja.

Meskipun pada Perpustakaan Daerah Provinsi Lampung menggunakan baik itu sistem klasifikasi dengan manual ataupun sistem klasifikasi digital dengan aplikasi E-DDC tersebut, pustakawan di perpustakaan tersebut masih lebih sering menentukan nomor klasifikasi menggunakan sistem klasifikasi manual karena jika menggunakan E-DDC masih terkendala jika komputer/laptop sedang bermasalah, walaupun demikian penggunaan aplikasi E-DDC tetap digunakan oleh pustakawan tersebut

\section{E. KESIMPULAN}

Penggunaan sistem klasifikasi di Perpustakaan Daerah Provinsi Lampung menggunakan dua sistem klasifikasi yaitu dengan sistem manual dan dengan sistem digital menggunakan aplikasi E-DDC (Electronic-Dewey Decimal Classification). Pustakawan Perpustakaan Daerah Provinsi Lampung menggunakan 7 buku pedoman klasifikasi dalam menentukan nomor klasifikasi bahan pustakanya, sedangkan untuk penggunaan aplikasi E-DDC pustakawan Perpustakaan Daerah Provinsi Lampung menggunakan E-DDC edisi 23. Walaupun menggunakan dua sistem klasifikasi, namun sistem manual yang masing sering digunakan oleh pustakawan Perpustakaan Daerah Provinsi Lampung, meskipun begitu 
aplikasi E-DDC masih tetap digunakan tetapi jarang, karena terkadang mendapatkan kendala saat ingin menggunakannya.

\section{DAFTAR PUSTAKA}

Dinas Perpustakaan dan Kearsipan. "Tentang Kami." Perpusda Provinsi Lampung, 2021. https://perpusda.lampungprov.go.id/pages/tentang-kami.

Fadilla, Nurul. 2021. "Komparasi Pemikiran Berwick Sayers Dan Mary Mortimer Tentang Sistem Klasifikasi Perpustakaan.” Jurnal Pustaka Ilmiah 6 (2): 1065. https://doi.org/10.20961/jpi.v6i2.46421.

Fijas, Felya Invita, dan Marlini Marlini. "Pelestarian dan Pemeliharaan Koleksi Bahan Pustaka di SMA Negeri 3 Tualang Kabupaten Siak Provinsi Riau.” Baitul 'Ulum: Jurnal Ilmu Perpustakaan dan Informasi 4, no. 2 (2021): 61-76. https://doi.org/10.30631/baitululum.v4i2.63.

Hutasoit, Hidayatil Raudah. 2014. "Perpustakaan Dan Penyebaran Informasi." Iqra': Jurnal Perpustakaan Dan Informasi 08 (02): 177-84. http://repository.uinsu.ac.id/171/.

Indah, Rosiana Nurwa. "Alternatif Aplikasi Mudah Perpustakaan (Pengenalan Aplikasi ASP.Net ).” Baitul 'Ulum: Jurnal Ilmu Perpustakaan dan Informasi 3, no. 1 (2020): 48-56. https://doi.org/10.30631/baitululum.v3i1.42.

Kesuma, Mezan el-Khaeri, Irva Yunita, dan Feni Meilani. "Penerapan Aplikasi SLiMS Dalam Pengolahan Bahan Pustaka Di Perpustakaan Perguruan Tinggi." Jurnal Adabiya 23, no. 2 (2021): 248-54. https://doi.org/http://dx.doi.org/10.22373/adabiya.v23i2.10346.

Nugroho, Muhammad Bagus. 2015. "Mencermati Nomor-Nomor Opsional (Optional Number) Dalam Sistem Klasifikasi Persepuluhan Dewey Edisi 23 (DDC Edition 23).” Record and Library Journal 1 (1): 1689-99.

Persepsi, Hubungan, Pemustaka Tentang, Dengan Pemanfaatan, Sistem Telusur, Di Perpustakaan, and Sekolah Tinggi. 2015. "Hubungan Persepsi Pemustaka Tentang Sistem Klasifikasi Dewey Decimal Classification ( Ddc ) Dengan Pemanfaatan Sistem Telusur Elektronik" 2 (1): 78-88.

Persepsi, Hubungan, Pemustaka Terhadap, Dengan Pemanfaatan, Sistem Temu, The Relationship, Of The, Literature Perception, et al. 2019. "N-JILS Menggunakan OPAC ( Online Public Access Catalog ) The Dewey Decimal Classification ( DDC ) Classification System Using The Background System Using OPAC ( Online Public Access Catalog ) At The Sriwijaya Palembang Politechnic State Library . The Rela” 2 (2): 141-52. 
Qomariyah, Nurul, Nur Nafi'iyah, and Ayu Ismi Hanifah. 2018. “Klasifikasi Kategori Buku Pada Perpustakaan Teknik Informatika Universitas Islam Lamongan.” Joutica 3 (1): 159. https://doi.org/10.30736/jti.v3i1.203.

Rizqiyani, Vidya, Anggraini Mulwinda, dan Defi Mahadji. "Klasifikasi Judul Buku dengan Algoritma Nae Bayes dan Pencarian Buku pada Perpustakaan Jurusan Teknik Elektro." Jurnal Teknik Elektro 9, no. 2 (2017): 60-65. https://doi.org/10.15294/jte.v9i2.11658.

Ronaldo, Deddy, and Aderay Saputra. 2018. “Aplikasi Pelabelan Buku Dengan Decimal Dewey Classification (Ddc) Pada Perpustakaan Teknik Informatika Universitas Palangka Raya Berbasis Website." Jurnal Teknologi Informasi Jurnal Keilmuan Dan Aplikasi Bidang Teknik Informatika 12 (2): 24-29. https://doi.org/10.47111/jti.v12i2.529.

Sipil, Mahasiswa Teknik, and Smart Building. 1993. "Dengan Konsep Smart Building" Disusun Oleh : 5 (1): 34-46.

Ibrahim Bafadal. (2016). Pengelolaan Perpustakaan Sekolah, Jakarta: Bumi Aksara.

Nanda Mutia \& Suherman .(2018). Analisis Kemampuan Mahasiswa Dalam Menentukan Notasi Berdasarkan Sistem Klasifikasi DDC.Libria, Vol. 10, No. 1, Juni. 